\title{
Peak Flow Meter with Measurement Analysis
}

\author{
Anisa, Torib Hamzah, M. Ridha Mak'ruf \\ Electromedical Department of Engineering Poltekkes Kemenkes Surabaya \\ Jl. Pucang East Jajar No. 10, Surabaya, 60245, Indonesia \\ E-mail: anisajuli3@gmail.com,toribhamzah@yahoo.co.id,m.reedha@gmail.com
}

\begin{abstract}
Article Info
History Articles:

Received May 15, 2020

Revised Nov 14, 2020

Accepted Nov 25, 2020

\section{Keywords: \\ Peak Flow Meter \\ PFR}

MPX5100GP

Abstract

The Peak flow meter is a device used to measure the amount of airflow in the human airway or often referred to as PFR (Peak Flow Rate). Peak Flow Rate (PFR) measurement is a simple and reliable way to detect airway obstruction. PFR measurement is a simple, non-invasive, fast and economic method to assess the strength and speed of expiration in $L$ / min, through maximum expiration of capacity total lung. The results of peak flow data can illustrate early warning signs for an illness that in some cases may show a decrease in lung function 1-3 days before other respiratory symptoms become apparent. This module is designed using MPX5100GP sensor. This sensor has a pressure range of 0-100 Kpa. The Nature module is also equipped with data storage facilities using an SD Card so that the measurement data can be processed using Ms. Excel to find out graph data for further diagnostic purposes. The inspection results can be directly viewed on the display and also automatically stored in the SD Card storage that has been available. This module has the highest error rate of $4.41 \%$ and the lowest error value of $0.42 \%$ compared to the original device. From the data collection that has been done, it can be concluded that this module can be used for the inspection process.
\end{abstract}

This job open access articles and licensed under Creative Commons Attribution-Non-Commercial $4.0 \quad$ License International,
Torib Hamzah

Electromedical Department of Engineering

Poltekkes Kemenkes Surabaya

J1. Pucang East Jajar No. 10, Surabaya, 60245, Indonesia

E-mail: toribhamzah@yahoo.co.id

\section{INTRODUCTION}

The peak flow meter is a device used to measure the amount of airflow in the human airway or often referred to as PFR (Peak Flow Rate). Peak Flow Rate (PFR) measurement is a simple and reliable way to detect airway obstruction [1]. PEFR is the maximum airflow rate achieved during forced expiration after maximum inspiration [2]. Measurement of peak expiratory flow is a simple, non-invasive, and economical method to determine the speed and strength of expiration, in liters per minute, with forced expiration of total lung capacity. Peak expiratory flow (PEF), also called peak expiratory flow rate (PEFR) is a person's maximum expiratory speed, as measured by a peak flow meter, a small handheld device used to monitor one's ability to breathe air [3]. It measures the flow of air through the bronchi and thus the level of obstruction in the airways. PEFR is defined as the maximum flow achieved during expiration given with maximum strength starting from maximal lung inflation [4]. Peak expiratory flow rate (PEFR) is the maximum flow rate produced during strong breathing, starting with full lung inflation. The peak flow rate mainly reflects large airway flow and depends on the voluntary effort and muscle strength of the subject [5]. APE is the maximum amount of airflow that can be reached at expiration by a maximum forced effort of total lung capacity. APE value is influenced by several factors. Factors that influence a person's APE score are age, sex, height, weight, smoking habits, and environmental and exercise factors [6].

APE value is obtained from the best peak flow value that can be achieved by the patient so that the patient's respiratory obstruction level can be identified. The value of peak flow rate (PEFR) can be influenced by several factors namely age, height, and gender [7]. Bronchial asthma is a disease that causes significant morbidity and mortality. It is projected to increase at an alarming rate with an estimated prevalence of 400 million by 2025, in contrast to the current 300 million. Peak flow meters are one of the simplest ways to objectively assess and monitor airway functions [8]. Monitoring this disease involves subjective and objective modalities. The results of peak flow data can illustrate early warning signs for a disease which in some cases may show a decrease in lung function 1-3 days before other respiratory symptoms become clear.

According to the World Health Organization (WHO) in 2004 lung diseases included 10 causes of death in the world including Chronic Obstructive Pulmonary Disease (COPD) (5.1\%), pulmonary TB $(2.5 \%)$, and lung cancer $(2.3 \%)$. Chronic obstructive pulmonary disease with bronchial asthma ranks sixth [6]. According to data from the Global Initiative for Asthma [9] (GINA, 2015), there are 300 million people worldwide suffering from bronchial asthma in various age groups and increasing, 
especially in developed countries. Based on the Global Initiative for Asthma, asthma is a major public health problem in all countries of the world and there are 300 million people with asthma worldwide and is expected to continue to increase to 400 million by 2025 . One in 250 people who die is asthma sufferers and around 180,000 deaths per year are caused by asthma with the most deaths at age $>45$ years. In Indonesia, asthma is included in the top ten causes of pain. It is estimated that the prevalence of asthma in Indonesia is 5\% of the total population of Indonesia, meaning that there are 12.5 million asthma patients in Indonesia (Zibetra 2015).

The World Health Organization (WHO) estimates the incidence of respiratory infections in developing countries with a mortality rate of 15 percent -20 percent per year in toddlers. In Indonesia, respiratory infections always rank first in the cause of death in infants and toddlers. Based on the prevalence of respiratory infections in 2016 in Indonesia has reached 25 percent with a range of events that are around 17.5 percent- 41.4 percent with 16 provinces of which have a prevalence above the national rate. Besides respiratory infections are also often in the list of 10 most diseases in the hospital [10]. In addition to infections of the respiratory tract, other disorders that occur in the respiratory tract are asthma. Asthma is a chronic respiratory disease characterized by inflammation, increased reactivity to various stimuli, and airway obstruction that can return spontaneously or with appropriate treatment. The global burden for this disease is increasing. Adverse effects of asthma include a decrease in quality of life, decreased productivity, absence from school, increased health costs, the risk of hospitalization and even death. Asthma in Indonesia is included in the top ten diseases that cause illness and death [11]. Asthma has affected more than 5 percent of the world's population, and several indicators have shown that its prevalence continues to increase.

Asthma control monitoring needs to be done to know the development of the effectiveness of asthma therapy. In addition to using treatment therapy, monitoring asthma control can be done by examining lung function. This is measured by a peak flow meter, which is a simple, portable handheld device, which is used to monitor a person's ability to release air through the bronchi. Thus it can provide an idea of the level of obstruction in the airways [12]. Home care includes self-monitoring using a peak expiratory flow device (PEF) and a written asthma action plan [13]. Changes in lung function variability can be detected with peak expiratory flow (PEF) values measured with a peak flow meter that can be used for objective measurements of daily respiratory limitations by patients [14]. This device is used by people with asthma to monitor their condition by following an asthma action plan developed by service providers that include self-monitoring of airway obstruction or symptoms. Using PEFR measurements is more economical and more available, therefore it is proposed as an alternative to spirometry [15]. PEFR measurement is a simple, non-invasive, fast and economical method to assess the strength and speed of expiration in L / min, through maximal expiration of total lung capacity [16]. Measurements through peak flow meters produce readings in 3 categories, according to the article "The Peak Flow
Meter and Its Use In Clinical Practice" by B O Adenlyl and G Erhabor namely the green zone, the yellow zone, and the red zone. The green zone shows that the patient is in good condition with peak flow valued at more than $80 \%$. Yellow zone means the patient is on alert, this can be caused by the patient experiencing some symptoms before asthma recurs due to exposure to asthma triggers with peak flow values between $50 \%$ - 79\%. While the red zone indicates that patients need further action with peak flow measurement results of less than $50 \%$. In the research that has been done, it can be concluded that there is no significant difference in the average value of PEFR from peak flow meters and spirometers. Because of this, peak flow meters can be used as an inexpensive, safe, easy-to-use, and sensitive tool to assess obstructive airway diseases, where spirometry is not available [17].

This peak flow meter tool has been made by Devie Muslimatun Nisa, 2012 with the title Peak Flow Meter based on AT89S51 Microcontroller (equipped with PEFR Normal / abnormal value). The weakness of the tool is the use of DC Fan so that the data obtained is less accurate. In 2015, a Digital Peak Flow Meter tool was developed using an MPX5100 pressure sensor by Indah Lindari. Weaknesses of the tool are that it cannot be applied in data storage. In 2017, Ika Safitri developed the tool with the title of Portable Peak Flow Meter equipped with SDcard Storage, but the device could not classify the diagnosis results on patients. In 2019 a Peak Flow Meter tool was developed with Nadiya Garnis Sallyfan's Inspection Result Indicator. The weakness of the tool is that it cannot be used portable because the device must be connected to a PC to display the inspection results. Based on the identification of these problems, the authors plan to create a module with the title "Peak Flow Meter Portable Equipped with Inspection and Storage Results" to facilitate the use of patients with portable device designs and ease to evaluate the results of previous examinations through data storage on the SD Card for further analysis purposes.

\section{MATERIALS AND METHODS}

\section{A. Experimental Setup}

This study used the object measurement that was made for male and female gender patients aged 20 years and over with height 160-175 cm (for male) and height 150-165 cm (for female).

\section{1) Materials and Tools}

This study used a pressure sensor MPX5100GP. Components used as a sensor microcontroller Arduino Nano, SDCard module, RTC DS3231, Oled LCD as the display.

\section{2) Trial}

In this study, an experiment was conducted on patients with data taking on the Rossmax type PF120A peak flow meter using a disposable mouthpiece. The data that has been obtained will be stored on the SD card and processed to produce graphic data on Ms. Excel. 


\section{B. Block diagram and flowchart}

The patient will exhale as much as possible through the mouthpiece that will be used as sensor input. Data output from the sensor will be processed on the microcontroller a data processor on the instrument. The measurement results will be displayed on the tool display in the form of digital data. The processed data will also be entered into the RTC to do the measurement time measurement process and will be stored on the SD Card in the form of txt can be seen in the fig. 1

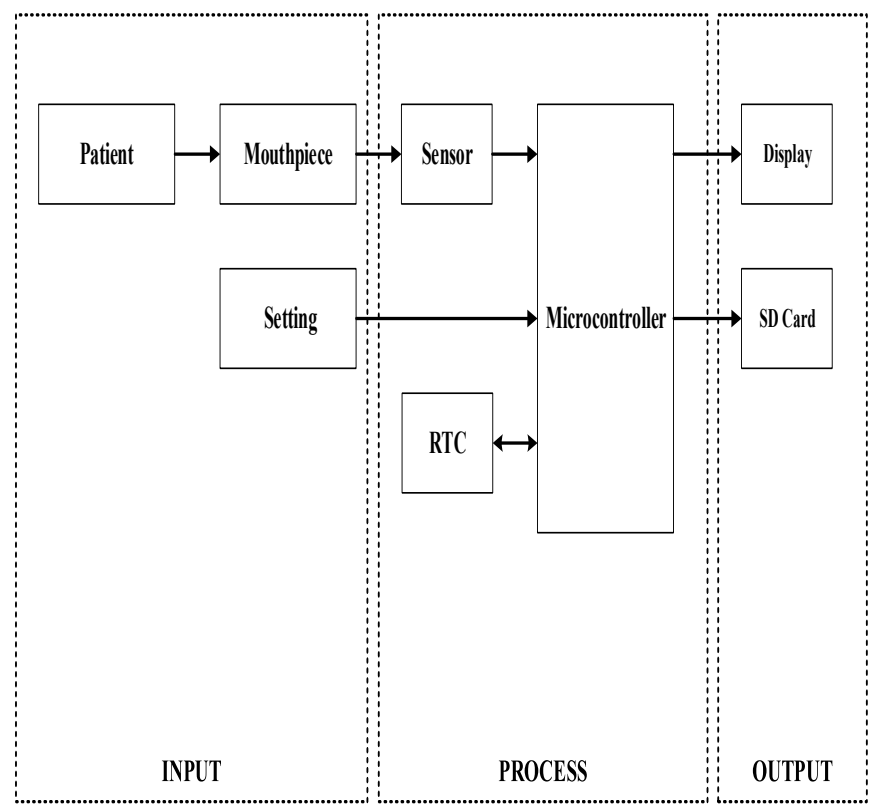

Fig. 1. A block diagram of Peak Flow Meter

\section{The Flowchart}

The program starts with the initials variable. Patients enter data in the form of height, age, and gender on the instrument. If the data is correct then the display will show ready for inspection. The patient blows the mouthpiece, then the ADC data coming from the sensor output will be processed in the microcontroller. The data will be processed with RTC to find out the measurement time and the data will be stored in the SD card in txt format

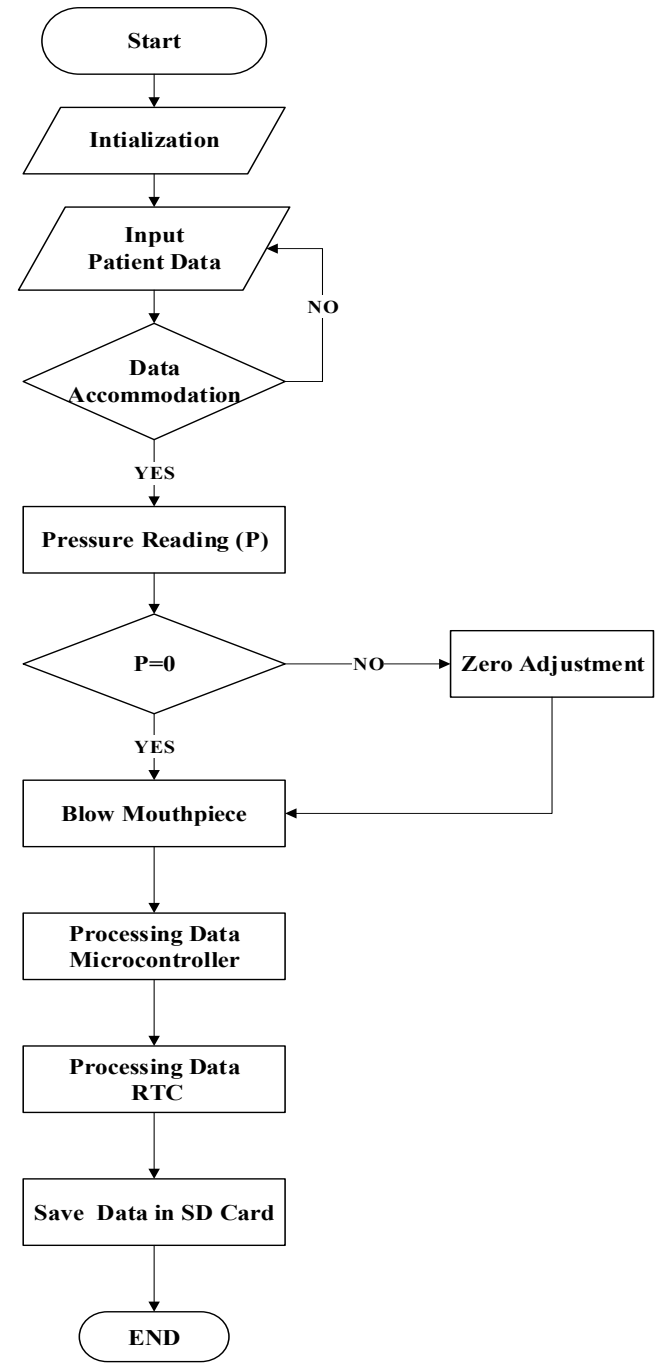

Fig. 2. The Flowchart Program Arduino

D. Circuits

1) Sensor Circuit

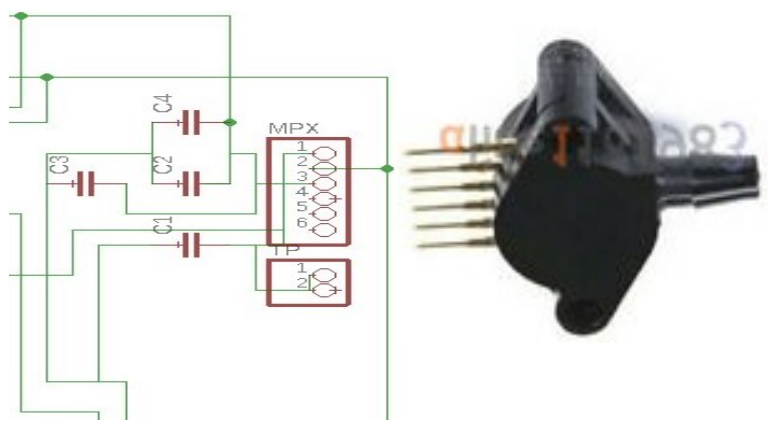

Fig. 3. Sensor Circuit 
In fig 3 In the sensor MPX5100GP with a capacitor that serves as DC Coupling according to the value contained in the datasheet.

\section{RESULT}

This tool uses Arduino Nano microcontroller for data processing, RTC module DS3231, and SD Card module for storage features. RTC is used to display time data as the X-axis on the graph. Whereas on the $\mathrm{Y}$-axis there is a flow value obtained from the sensor. Can be seen to fig 4

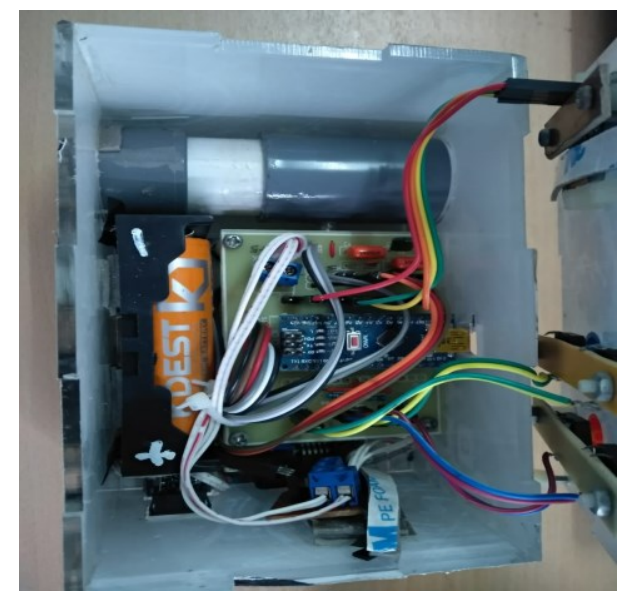

Fig. 4. Peak Flow Meter Circuit

\section{1) Peak Flow Meter Design}

Image design tools can be seen in Fig. 4. There is a pipe as input for the disposable mouthpiece. The pipe is $2.6 \mathrm{~cm}$ in diameter. The sensor is connected to the pipe to detect the amount of airflow exhaled by the patient.

\section{2) Results Peak Flow Meter Program}

In this study, there are 3 main program parts, namely the process of converting pressure into the flow, a program to obtain inspection results, and a storage program.

Listing program 1 . The program to convert pressure into flow

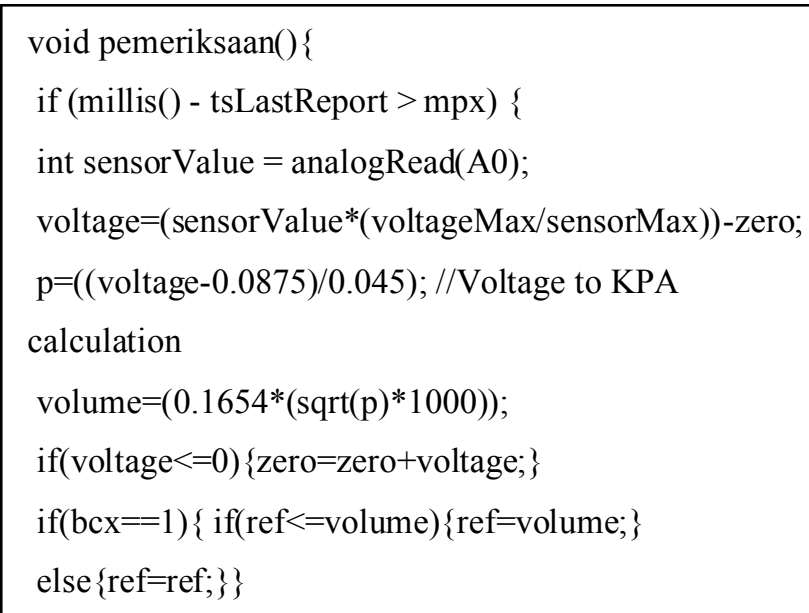

In the listing program 1 . there is a conversion of pressure to flow rate which is detected through sensor.

Listing program 2. The program to obtain inspection results

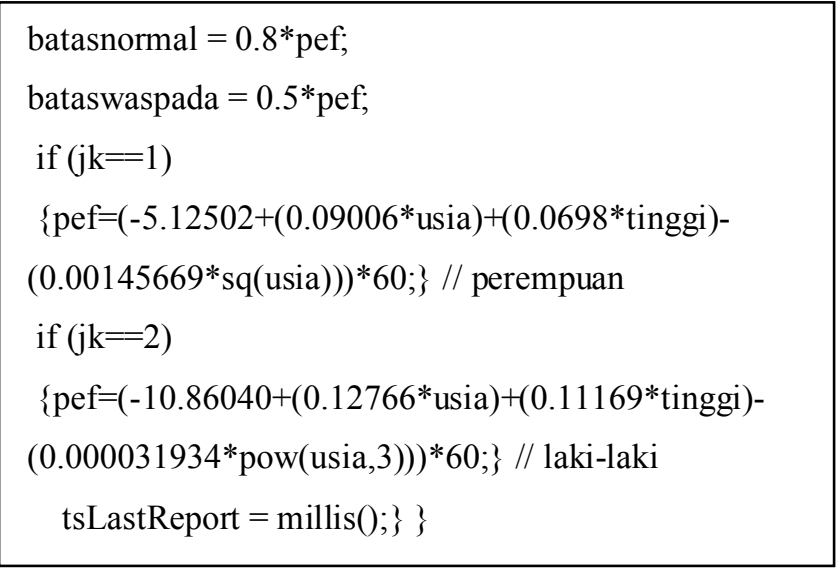

In listing program 2. is a program to obtain the results of examinations that have been zone results carried out by patients in the form of normal values from these patients and the classification or measurements.

Listing program 3. The storage Program

Listing program 3 . is a program to obtain data that will be storage to the SD Card.

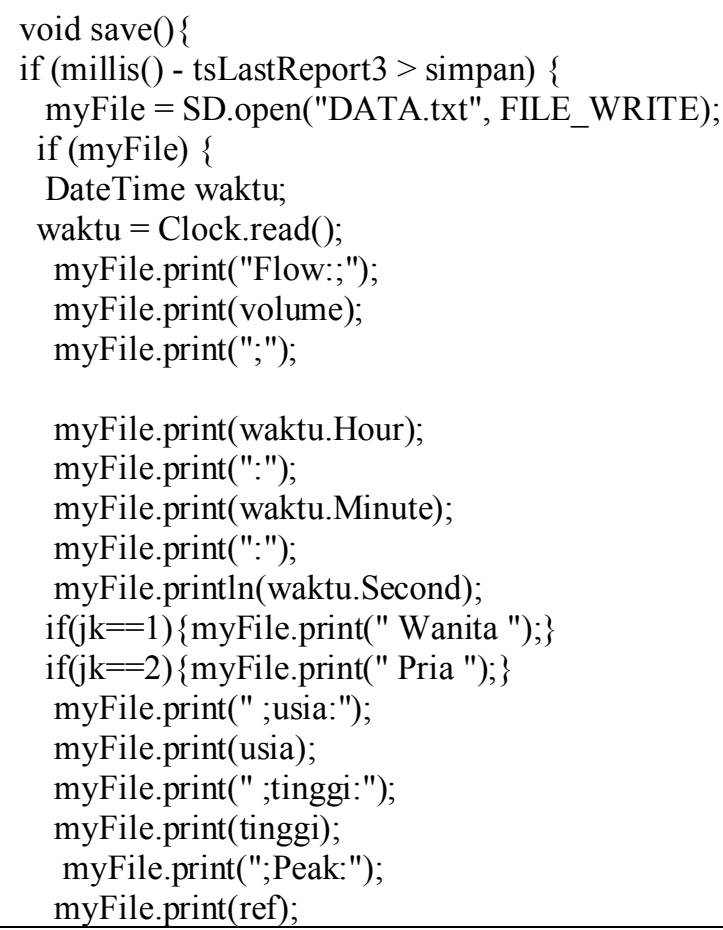


myFile.print(";normal:");

myFile.print(batasnormal);

if(kondisi==1) \{myFile.print(";HIJAU ;");

if(kondisi==2) \{myFile.print(";KUNING;");

if(kondisi==3) \{myFile.print(";MERAH ;");\}

myFile.close ()$;\}$

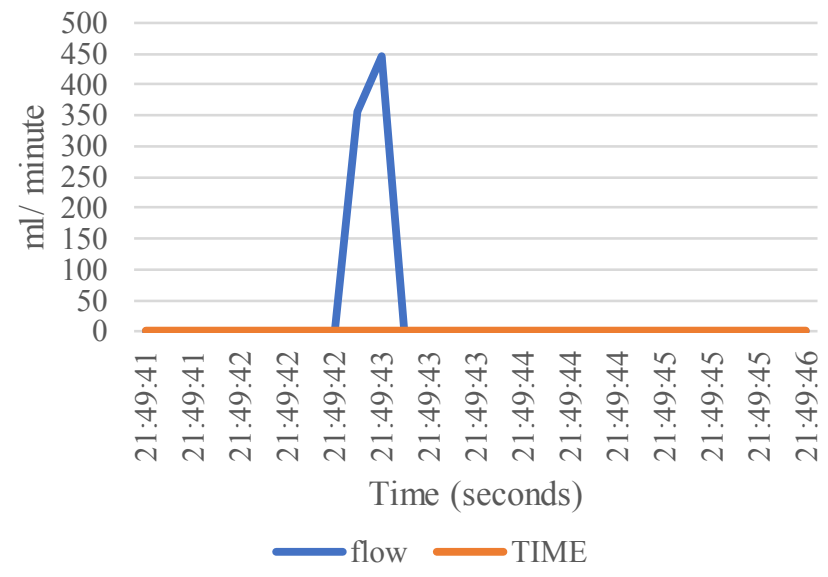

Fig. 5. Respondence response

After the patient's data has been saved, the data is transferred to Ms. Excel to generate graph data. Data stored on the SD Card is in the form of txt. data that has been processed on Ms. Excel contains data when measurements are taken on the $\mathrm{X}$-axis and patient data flow on the $\mathrm{Y}$-axis.

TABLE I. COMPARISON OF CALCULATION AND MEASUREMENT OF PRESSURE ON THE MPX5100GP SENSOR.

\begin{tabular}{cccc}
\hline $\begin{array}{c}\text { Volt } \\
\text { (Volt) }\end{array}$ & $\begin{array}{c}\text { Measurement } \\
\text { (Kpa) }\end{array}$ & $\begin{array}{c}\text { Calculation } \\
\text { (Kpa) }\end{array}$ & $\begin{array}{c}\text { Error } \\
(\mathbf{\%})\end{array}$ \\
\hline $\mathbf{0 . 2 7}$ & 4.03 & 4.05 & -0.49628 \\
\hline $\mathbf{0 . 3 2}$ & 5.12 & 5.16 & -0.78125 \\
\hline $\mathbf{0 . 4 3}$ & 7.5 & 7.6 & -1.33333 \\
\hline $\mathbf{0 . 4 8}$ & 8.7 & 8.72 & -0.22989 \\
\hline $\mathbf{0 . 5 2}$ & 9.57 & 9.61 & -0.41797 \\
\hline $\mathbf{0 . 5 4}$ & 10 & 10.05 & -0.5 \\
\hline $\mathbf{0 . 5 9}$ & 11.09 & 11.16 & -0.6312 \\
\hline $\mathbf{0 . 6 4}$ & 12.28 & 12.27 & 0.081433 \\
\hline $\mathbf{0 . 6 8}$ & 13.15 & 13.16 & -0.07605 \\
\hline $\mathbf{0 . 7 3}$ & 14.35 & 14.27 & 0.557491 \\
\hline $\mathbf{0 . 7 6}$ & 15 & 14.94 & 0.4 \\
\hline & Average & & 0,952 \\
\hline
\end{tabular}

TABLE II. MODULE ERROR VALUE COMPARED TO STANDARDIZED EQUIPMENT PFM ROSSMAX PF120A

\begin{tabular}{ccc}
\hline No. & Subject & Error (\%) \\
\hline $\mathbf{1}$ & P1 & 0.423729 \\
$\mathbf{2}$ & P2 & -2.020441 \\
\hline $\mathbf{3}$ & P3 & 4.411765 \\
\hline $\mathbf{4}$ & P4 & 3.307888 \\
\hline $\mathbf{5}$ & P5 & 2.877698 \\
\hline $\mathbf{6}$ & P6 & 3.361345 \\
\hline $\mathbf{7}$ & P7 & 1.303538 \\
\hline $\mathbf{8}$ & P8 & -3.21101 \\
\hline $\mathbf{9}$ & P9 & 0.552486 \\
\hline
\end{tabular}

\section{DISCUSSION}

MPX5100GP sensor has a pressure range of 0-100 KPa so that it can be used to detect the expiration rate of humans. The SD Card Module can be used to store the results of measurements made by patients in txt form which then the data is processed using Ms. Excel to produce graphical data for further analysis and diagnosis needs. The use of RTC is intended to display the time taken for measurement, in this module the time saved is hours, minutes and seconds which will then be taken for the analysis process on Ms. Excel as the X-axis. Through data retrieval that has been done to 9 patients, the highest error value is $4.41 \%$ and the lowest value is $0.42 \%$ compared to standardized equipment.

\section{Conclusion}

MPX5100Gp pressure sensor can be used to determine the expiration value of humans. The results of the inspection can be immediately known after the measurement is done and directly stored in the SD Card which is then processed in Ms. Excel to generate graph data. The highest error value of this module is $4.41 \%$ and the lowest is $0.42 \%$. replacement of tool designs with displays that can directly produce graph data will be easier and more effective.

\section{REFERENCE}

[1] S. M. Gururaja, "Comparison of peak expiratory flow rate in healthy urban and rural school children in and around Bangalore : a cross sectional study," vol. 3, no. 1, pp. 77-82, 2016.

[2] S. K. Padaki, D. Amrut, and P. Kokiwar, "Peak expiratory flow rate in asymptomatic male workers exposed to chemical fumes, in various industries of Hyderabad," Int. J. Med. Res. Heal. Sci., vol. 3, no. 4, p. 870, 2014.

[3] S. Mohanty, E. Venkatarao, S. Yasobant, and D. Vijaykumar, "What lessons India must learn from Physical Activity promotion models?: An Integrative 
review of 2 successful Models," Int. J. Recent Sci. Res., vol. 10, no. 5, pp. 32535-39, 2019.

[4] M. Metha, "To find out the effect of various body positions on peak expiratory flow rate (pefr) in copd patients," vol. 3, no. 3, pp. 291-296, 2016.

[5] M. K. Singh and A. S. Solanki, "A study of Peak expiratory flow rate and Vital capacity between Indoor and Outdoor games male players," vol. 3, no. 1, pp. 79, 2016.

[6] R. Alimmattabrina, M. S. Anam, and N. Arkhaesi, "Hubungan Antara Peak Expiratory Flow Rate Dengan Prestasi Belajar Kognitif Pada Anak Usia 10 Sampai 12 Tahun," J. Kedokt. Diponegoro, vol. 4, no. 4, pp. 1425$1432,2015$.

[7] A. Lorensia, D. De Queljoe, and K. A. Santosa, "Kelengkapan informasi mengenai cara penggunaan peak flow meter yang diberikan kepada pasien asma di apotek," vol. 1, no. 2, pp. 200-206, 2015.

[8] F. B. Irani and P. U. Shinde, "RESEARCH ARTICLE PEAK EXPIRATORY FLOW RATE ( PEFR ): CONCLUSION AND RECOMMENDATION."

[9] B. O. Adeniyi and G. E. Erhabor, "The peak flow meter and its use in clinical practice," African J. Respir. Med., pp. 5-8, 2011.

[10] S. Natarajan, J. Castner, and A. H. Titus, "Smart phonebased peak expiratory flow meter," vol. 52, no. 11, pp. 904-905, 2016.

[11] D. I. Rs and H. S. Kendal, "TRIPOD TERHADAP LAJU PERNAFASAN PASIEN PPOK Penyakit Paru Obtruktif Kronis ( PPOK ) atau Chronic Obstructive Pulmonary Diseases ( COPD ) adalah penyakit yang ditandai adanya hambatan aliran pernafasan bersifat reversible sebagian dan progresif yang berhub."

[12] B. Mehta, K. Garg, S. Ambwani, B. Bhandari, and O. L. Bhagat, "Peak Expiratory Flow Rate : A Useful Tool for Early Detection of Airway Obstruction in School Children," pp. 159-165, 2016.

[13] S. Natarajan, J. Castner, and A. H. Titus, "Smart phone compatible peak expiratory flow meter," 2014 IEEE Healthc. Innov. Conf. HIC 2014, pp. 141-144, 2014.

[14] A. Lorensia, Z. Ikawati, T. M. Andayani, and D. Maranatha, "ORIGINAL ARTICLE PERBANDINGAN PERBAIKAN NILAI PEAK EKSPIRATORY FLOW PENGGUNAAN Asma merupakan penyakit heterogen yang mempengaruhi 1$18 \%$ populasi di dunia, ditandai dengan gejala mengi , sesak napas, sesak dada , dan batuk, saluran napas . 1 Di Indones," vol. 5, no. 2, 2018.

[15] C. Pothirat et al., "Peak expiratory flow rate as a surrogate for forced expiratory volume in I second in
COPD severity classification in Thailand," Int. J. COPD, vol. 10, pp. 1213-1218, 2015.

[16] U. Bedi, "A study of peak expiratory flow rate in normal healthy children of Punjab," Int. J. Med. Dent. Sci., vol. 5, no. 1, pp. 1042-1047, 2016.

[17] S. Bansal, V. Tiwari, S. Sood, and R. Shukla, "Comparative Evaluation of Peak Expiratory Flow Rate between Computerized Spirometry and Peak Flow Meter," Int. J. Adv. Integr. Med. Sci., vol. 1, no. 3, pp. 93-94, 2016. 